\section{Analisis Hukum Ekonomi Syariah Terhadap Jual Beli Melalui Media Online Di Kalangan Mahasiswa}

\author{
Zuhrotul Mahfudhoh, Lukman Santoso* \\ Institut Agama Islam N egeri Ponorogo (IAIN) Ponorogo
}

\section{SERAM BI}

Received 15 Feb 2020

Revised 18 Apr 2020

Accepted 25 A pr 2020

Online first $30 \mathrm{Apr} 2020$

\begin{abstract}
A bstract
Purpose: This study aims to find out (1) how IAIN Ponorogo students think about buying and selling online and (2) how Islamic sharia economic analysis of buying and selling through online media among IAIN Ponorogo students. Method: Field research is used with a qualitative approach to explaining the actual state of research that produces descriptive data in the form of observed words and behavior. The results of the study were analyzed by the deductive method, which starts with general facts and then ends with a special conclusion. Finding: first, online sellers and buyers feel the benefits of online media that are very easy, practical, timesaving, cheaper, and do not require capital for online sellers. Second, buying and selling meet directly between the seller and the buyer. However, according to the development of the era of buying and selling through online media, including aspects of muamalah which basically are permissible (permissible) unless there is an argument that forbids them. .
\end{abstract}

\begin{abstract}
A bstrak
Tujuan- Penelitian ini bertujuan untuk mengetahui (1) bagaimana pendapat mahasiswa IAIN Ponorogo mengenai jual beli online serta (2) bagaimana analisis hukum ekonomi syariah terhadap jual beli melalui media online di kalangan mahasiswa IAIN Ponorogo. Metode: Penelitian lapangan (field research) digunakan dengan pendekatan kualitatif untuk menjelaskan keadaan aktual dari penelitian yang menghasilkan data deskriptif berupa kata-kata dan perilaku yang diamati. Hasil penelitian dianalisis dengan metode deduktif, yaitu diawali dengan kenyataan yang bersifat umum kemudian diakhiri dengan kesimpulan khusus. Temuan: pertama, penjual dan pembeli online merasakan kemanfaatan media online yang sangat mudah, praktis, hemat waktu, lebih murah, dan tidak memerlukan modal bagi penjual online. Kedua, pada dasarnya jual beli bertemu secara langsung antara penjual dan pembeli. Namun, sesuai perkembangan zaman jual beli melalui media online termasuk aspek muamalah yang pada dasarnya mubah (boleh) kecuali ada dalil yang mengharamkannya.
\end{abstract}

Pedoman Sitasi: Mahfudhoh, Z \& Santoso, L. (2020). Analisis Hukum Ekonomi Syariah Terhadap Jual Beli Melalui Media Online Di Kalangan Mahasiswa. SERA M BI: Jurnal Ekonomi M anajemen dan Bisnis Islam, 2(1), 29 - 40.

D 0I: https:/ / doi.org/ 10.36407/ serambi.v2i1.143

\author{
Paper type \\ Research paper \\ Email : \\ lukmansantoso4@gmail.com
}

Keywords: Hukum Ekonomi Syariah, Jual Beli, Online, $M$ ahasiswa

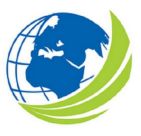

SERAMBI: Jurnal Ekonomi dan Bisnis Islam, Vol 2, No.1, 2020, pp. $29-40$

elSSN 2685-9904 


\section{Pendahuluan}

Kegiatan jual beli pada umumnya dilakukan dengan bertemu langsung antara penjual dan pembeli di suatu tempat seperti pasar. Namun, saat ini kegiatan jual beli sudah dapat dilakukan dengan cara yang lebih mudah menggunakan sistem online dari gawai yang sudah terkoneksi dengan internet. Jika berbicara mengenai bisnis on line, seharusnya tidak hanya berbicara tentang pangsa pasar yang ada di Indonesia, tetapi dunia. Karena melalui internet, semua orang yang ada di dunia bisa saling berhubungan dan berinteraksi dengan tidak mengenal waktu dan tempat (Igen, 2010).

Indonesia merupakan salah satu pangsa pasar bisnis online yang besar. Data dari Asosiasi Penyelenggara Jasa Internet Indonesia (APJII) dalam buletin bulan Maret 2018 memaparkan bahwa pengguna jasa internet Indonesia mencapai 143,26 juta penduduk atau setara dengan 54,7 penduduk Indonesia. Internet memberikan berbagai kemudahan kepada masyarakat untuk bertransaksi antar pulau hingga antar negara. Akibatnya, tren bisnis online meningkat secara dramatis di semua kalangan. Selain itu, bisnis online bisa menjadi alternatif untuk mengatasi pengangguran, karena seseorang dapat memulai usahanya tanpa mengeluarkan modal yang besar (Albarri, 2019).

Hikmah disyariatkannya jual beli ialah bahwa hidup bermasyarakat merupakan karakter manusia yang telah Allah SWT ciptakan, diciptakannya Ielaki dan perempuan, kemudian berbangsa-bangsa dan bersuku-suku agar saling mengenal di antara mereka. Kemudian Allah SWT menitipkan mereka naluri saling tolong menolong untuk memenuhi kebutuhan hidupnya. Untuk menjembatani hal tersebut, maka Allah SWT mensyariatkan jual beli sebagai jalan yang adil. (Hidayat, 2015) Diharapkan dalam sistem jual beli harus ada sikap saling menguntungkan, baik yang bersifat sosial maupun keuntungan yang bersifat ekonomi (Nawawi, 2012).

Pesatnya perkembangan bisnis jual beli online telah menarik para peneliti untuk mengetahui hukum jual beli dari perspektif hukum Islam. Beberapa studi seperti Fitria (2017), Nawawi \& Rosyadi (2019), Lestari \& Wahab (2018), Purwanto (2018), Firmansyah \& Widodo (2019) mencoba menjelaskan hukum jual beli online dalam perspektif Islam. Fitria (2017) dengan pendekatan kajian literatur memberikan kesimpulan bahwa bisnis online tidak melanggar hukum islam selama tidak memiliki unsur riba, ketidakadilan, monopoli dan penipuan. Dengan demikian, jual beli online dapat dinyatakan halal berdasarkan persetujuan (A ntaradhin). Nawawi \& Rosyadi (2019) menyimpulkan bahwa transaksi apa pun dan apa pun produknya, selama tidak mengandung hal-hal yang menyebabkan salah satu pihak dalam transaksi dan barang yang diperdagangkan bukanlah barang terlarang dan dilarang baik oleh hukum agama (hukum Islam) serta barang atau benda yang tidak bersih dan terlarang seperti narkoba dan atau oleh hukum negara serta barang curian, korupsi, pencucian uang, maka hal itu diperbolehkan.

Dalam perspektif yang berbeda, Lestari \& Wahab (2018) meneliti hukum Islam terhadap objek akad jual beli online dengan sistem dropshipping pada sebuah toko online. Mereka menyimpulkan bahwa tidak terpenuhinya syarat dari rukun objek aqd, sebab terdapat perbedaan antara kondisi barang contoh dengan kondisi barang real yang akan diterima konsumen nantinya, sehingga hukum jual beli tersebut menjadi tidak sah. Dalam konteks yang sama yaitu sistem dropshipping, Purwanto (2018) menyimpulkan bahwa dari sisi hukum ekonomi syariah status pelaksanaan jual beli dengan sistem dropshipping dengan melakukan kontrak terlebih dahulu dengan pihak distributor dibolehkan. Namun, dropshipping yang tidak melakukan kontrak terlebih dahulu dapat diketegorikan sebagai akad yang bathal. Bathal nya akad dropshipping ini dikarenakan adanya unsur yang tidak memenuhi rukun dan syarat terbentuknya suatu akad serta mengandung unsur gharar. 
Penelitian ini bertujuan untuk mengembangan studi dengan fokus pada analisis hukum ekonomi syariah terhadap jual beli melalui media online di kalangan mahasiswa IAIN Ponorogo. Isu ini didasarkan pada fakta di lapangan yang memperlihatkan bahwa berbelanja secara online sudah dinikmati sebagian besar di kalangan mahasiswa IAIN Ponorogo. Ada beberapa mahasiswa yang memilih berbisnis jual beli online sambil kuliah untuk mendapatkan tambahan uang saku atau sebagai sampingan. Bisnis jual beli online sangat viral di kalangan masyarakat atau pun mahasiswa di IAIN Ponorogo. Di kampus IAIN Ponorogo, ada beberapa fakultas yaitu Fakultas Syariah, Fakultas Ekonomi Bisnis Islam, Fakultas Tarbiyah dan IImu Keguruan, dan Fakultas Ushuluddin, Adab dan Dakwah. Studi ini dapat bermanfaat untuk menegaskan aktivitas bisnis online dari sisi hukum Islam, sekaligus sebagai dasar rujukan untuk penelitian berikutnya yang mengambil isu serupa.

\section{Kajian Pustaka}

Konsep Hukum Ekonomi Syariah dan Jual Beli

Ekonomi syariah adalah usaha atau kegiatan yang dilakukan oleh orang per orang, kelompok orang, badan usaha yang berbadan hukum atau tidak berbadan hukum dalam rangka memenuhi kebutuhan yang bersifat komersial dan tidak komersial menurut prinsip syariah. Ekonomi syariah baik sebagai disiplin ilmu maupun sebagai sebuah sistem, kehadirannya tidak berlatarkan apologetic, dalam artian bahwa sistem ini pernah memegang peranan penting dalam perekonomian dunia yang diklaim sekarang sebagai suatu yang baik secara taken for granted. Kehadiran ekonomi syariah juga tidak disebabkan karena sistem ekonomi kapital is mengandung banyak kelemahan dan ketidakadilan. Ekonomi Islam datang karena tuntunan dari kesempurnaan Islam itu sendiri. Dalam kehidupan ekonomi, Islam telah memiliki sistem ekonomi tersendiri sebagaimana yang telah difirmankan oleh Allah SWT dalam AI-quran dan penjabarannya melalui As-sunah Rasulullah SAW (Manan, 2012).

Di Indonesia, ekonomi syariah tidak saja berkembang dalam bentuk booming lembagalembaga bisnis syariah secara masif, dinamisnya institusi pendidikan tinggi berbasis ekonomi syariah, tetapi juga dalam bentuk legeslasi ekonomi syariah dalam tata hukum nasional dengan terbitnya UU No. 3 Tahun 2006 tentang Perubahan atas UU No. 7 Tahun 1989 Tentang Peradilan Agama, UU No. 19 Tahun 2008 tentang Surat Berharga Syariah Negara, UU No. 21 Tahun 2008 tentang Perbankan Syariah, UU No. 48 Tahun 2009 tentang Kekuasaan Kehakiman, dan UU No. 50 Tahun 2009 Tentang Perubahan Kedua atas UU No. 7 Tahun 1989 Tentang Peradilan Agama (Yasin, 2014). Menurut Fatwa DSN MUI No. 24 Tahun 2017 Tentang Bermuamalah Melalui Media Sosial, bahwa bermuamalah adalah proses interaksi antar individu atau kelompok yang terkait dengan hubungan antar sesama manusia meliputi pembuatan (produksi), penyebaran (distribusi), akses (konsumsi), dan penggunaan informasi dan komunikasi. Media sosial adalah media elektronik, yang digunakan untuk berpartisipasi, berbagi, dan menciptakan isi dalam bentuk blog, jejaring sosial, forum, dunia virtual, dan bentuk lain.

D asar Hukum Jual Beli

Menurut Sayyid Sabiq, jual beli sebagai sarana tolong menolong antar sesama manusia. Islam membolehkan berdasarkan ayat-ayat Qur'an, Hadith-Hadith nabi dan Ijma' Ulama. 
Al-Qur'an

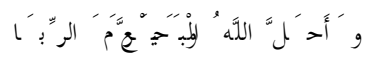

Artinya: "Allah telah menghalal kan jual beli dan mengharamkan riba". (QS. A I-

Baqarah: 275).

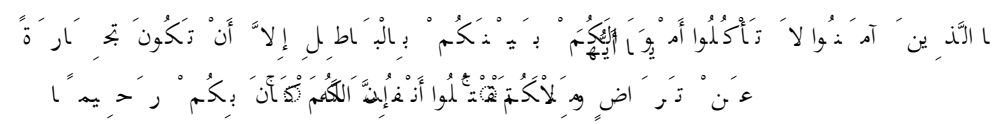

Artinya: "H ai orang-orang yang beriman, janganlah kamu saling memakan harta sesamamu dengan jalan yang batil, kecuali dengan jalan perniagaan yang berlaku dengan suka sama-suka di antara kamu. Dan janganlah kamu membunuh dirimu; sesungguhnya A llah adalah M aha Penyayang kepadamu" . (Q S. al-N isa: 29)

H Jadith

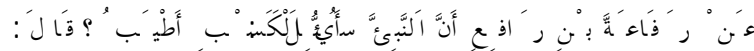

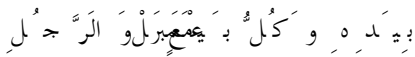

Artinya:"Dari Rifa"ah Ibnu Rafi" r.a. bahwa Rasulullah saw. pernah ditanya: Pekerjaan apakah yang paling baik?. Beliau bersabda: "Pekerjaan seseorang dengan tanganny dan setiap jual-beli yang mabrur"

Ijma'

Selain al-qur'an dan al-hadits, ulama telah sepakat bahwa jual beli diperbolehkan dengan alasan bahwa manusia tidak akan mampu mencukupi kebutuhannya sendiri tanpa bantuan orang lain, namun demikian bntuan atau barang milik orang lain yang dibutuhkannya itu harus diganti dengan barang yang lainnya yang sesuai (Syafei, 2006).

Jual Beli yang Diperbolehkan dan Dilarang dalam Islam

Menurut madhab Hanafi, Maliki, Shafi'i dan Hanbali hukum jual beli terbagi menjadi dua, yaitu jual beli yang diperbolehkan dalam Islam (yang sesuai dengan hukum shara') dan jual beli yang dilarang dalam Islam (yang bertentangan dengan hukum shara').

1. Jual beli yang diperbolehkan dalam Islam

Jual beli sahih, yaitu jual beli yang disyariatkan menurut asal dan sifatnya terpenuhi rukun-rukun dan syarat-syaratnya tidak terkait dengan hak orang dan tidak ada hak memilih di dalamnya. Jual beli sahih menimbulkan implikasi hukum, yaitu berpindahnya kepemilikan, yaitu berang berpindah miliknya menjadi milik pembeli dan harga berpindah miliknya menjadi milik pembeli (Rosalinda, 2016).

2. Jual beli yang dilarang dalam Islam

Jual beli yang dilarang dalam Islam sangatlah banyak, diantaranya yaitu:

a. Terlarang sebab ahliah (Ahli A kad)

Ulama sepakat bahwa jual beli di kategorikan sahih apabila dilakukan oleh orang yang baligh, berakal, dapat memilih, dan mampu ber-tas\{arruf secara bebas dan baik. Mereka di pandang tidak sah jual belinya adalah berikut ini (Syafe'i, 2001):

1) Jual beli orang gila. Ulama fiqih sepakat bahwa jual beli orang yang gila tidak sah. Begitu pula sejenisnys, seperti orang mabuk, sakalor, dan lain-lain.

2) Jual beli anak kedil. Ulama fiqih sepakat bahwa jual beli anak kedil di pandang belum sah, kecuali dalam perkara-perkara yang ringan atau sepele. 
3) Jual beli orang buta. Jual beli orang buta di kategorikan sahih menurut jumhur jika barang yang dibelinya di beri sifat (diterangkan sifat-sifatnya).

4) Jual beli terpaksa. Menurut ulama Hanafiyah dilarang, namun apabila orang yang terpaksa merasa bahwa sudah tidak terpaksa, maka jual belinya diperbolehkan. Sedangkan ulama Malikiyah menganggap tidak pantas. Sedangkan ulama Shafi'iyah dan Hanabilah tidak di perbolehkan atau dilarang.

5) Jual beli orang yang terhalang. Maksud terhalang disini adalah terhalang karena kebodohan, bangkrut, ataupun sakit. Jual beli orang yang bodoh yang suka menghamburkan hartanya, menurut pendapat ulama Malikiyah, Hanafiyah dan pendapat paling sahih di kalangan Hanabilah, harus ditangguhkan.

Adapun menurut ulama Shafi'iyah, jual beli tersebut tidak sah sebab tidak ada ahli dan ucapannya di pandang tidak dapat di pegang. Begitu pula ditangguhkan jual beli orang yang sedang bamgkrut berdasarkan ketetapan hukum, menurut ulama Malikiyah, Hanafiyah. Sedangkan menurut ulama Shafi'iyah dan Hanabilah, jual beli tersebut tidak sah (Syafe'i, 2001).

b. Terlarang sebab shighat

Ulama fiqih telah sepakat atas sahnya jual beli yang didasarkan pada keridaan di antara pihak yang melakukan akad, ada kesesuaian di antara ijab dan qabul, berada di satu tempat dan tidak terpisah oleh suatu pemisah. Jual beli yang tidak memenuhi ketentuan tersebut dipandang tidak sah. Beberapa jual beli yang dipandang tidak sah atau masih di perdebatkan oleh para ulama adalah sebagai berikut (Syafe'i, 2001; Nawawi, 2010):

1) Jual beli mu'atah. Ialah jual beli yang telah disepakati oleh pihak akad, berkenaan dengan barang maupun harganya, tetapi tidak memakai ijab qabul. Jumhur ulama menyatakan sahih apabila ada ijab qabul dari salah satunya. Begitu pula dibolehkan ijab qabul dengan isyarat perbuatan atau cara-cara lain yang menunjukkan keridaan. Memberi barang dan menerima uang dipandang sebagai shighah dengan perbuatan atau isyarat.

2) Jual beli melalaui surat atau melalui tulisan. Ulama fiqih sepakat bahwa jual beli surat atau utusan adalah sah. Tempat berakad adalah sampainya surat atau utusan dari aqid pertama kepada aqid kedua. Jika qabul melebihi tempat, akad tersebut di pandang tidak sah, seperti surat tidak sampai ke tangan yang dimaksud.

3) Jual beli dengan isyarat atau tulisan. Disepakati kesahihan akad dengan isyarat atau tulisan khususnya bagi yang uzur sebab sama dengan ucapan. Selain itu, isyarat juga menunjukkan apa yang ada dalam hati aqid. A pabila isyarat tidak dapat dipahami dan tulisanyya jelek (tidak dapat dibaca), akad tidak sah.

4) Jual beli barang yang tidak ada di tempat akad. Seorang muslim tidak boleh menjual sesuatu yang tidak ada padanya atau sesuatu yang belum dimilikinya, karena hal tersebut menyakiti pembeli yang tidak mendapatkan barang yang dibelinya.

5) Jual beli tidak sesuai antara ijab dan qabul. Hal ini dipandang tidak sah menurut kesepakatan ulama. Akan tetapi, jika lebih baik, seperti meninggikan harga, menurut ulama $\mathrm{H}$ \{anafiyah membolehkannya, sedangkan ulama Shafi'iyah menganggapnya tidak sah. 
6) Jual beli munji. Jual beli munjiz adalah yang dikaitkan dengan suatu syarat atau ditangguhkan pada waktu yang akan datang. Jual beli ini, dipandang batal menurut jumhur ulama.

c. Terlarang sebab barang jualan

Secara umum, ma'qud alaih adalah harta yang dijadikan alat pertukaran oleh orang yang akad, yang biasa disebut mabi' (barang jualan) dan harga. Ulama fiqih sepakat bahwa jual beli dianggap sah apabila ma'qud alaih adalah barang yang tetap atau bermanfaat, berbentuk, dapat diserahkan, dapat dilihat oleh orang-orang yang akad, tidak bersangkutan dengan milik orang lain, dan tidak ada larangan syara'. Selain itu, ada beberapa masalah yang disepakati oleh sebagian ulama, tetapi diperselisihkan ol eh ulama lainnya, diantaranya berikut ini (Hidayat, 2015; Nawari, 2012; Syafei, 201)

1) Jual beli benda yang tidak ada atau dikhawatirkan tidak ada. Jumhur ulama sepakat bahwa jual beli barang yang tidak ada atau dikhawatirkan tidak ada adalah tidak sah.

2) Jual beli barang yang tidak dapat diserahkan. Jual beli barang yang tidak dapat diserahkan, seperti burung yang ada di udara atau ikan yang ada di air tidak berdasarkan ketetapan shara'.

3) Jual beli gharar. Jual beli gharar ialah setiap akad jual beli yang mengandung resiko atau bahaya kepada salah satu pihak orang yang berakad sehingga mendatangkan kerugian finansial. Hal ini disebabkan karena adanya keraguraguan antara apakah barang yang diperjual belikan itu mulus atau tidaknya (ada cacat). Seperti barang yang di perjualbelikan itu tidak bisa di serahterimakan pada saat waktu akad.

4) Jual beli barang-barang haram dan najis. Seorang muslim tidak boleh menjual barang atau komoditas barang haram, barang najis, dan barang-barang yang menjurus kepada haram. Seperti khmar, babi, bangkai, berhala.

5) Jual beli air. Disepakati bahwa jual beli air yang dimiliki, seperti air sumur atau yang disimpan di tempat pemiliknya dibolehkan oleh jumhur ulama madzhab empat. Sebaiknya ulama Dhahiriyyah melarang secara mutlak. Juga disepakati larangan atas jual beli air yang mubah, yakni yang semua manusia boleh memanfaatkannya.

6) Jual beli yang tidak ada pada penjual. Seorang muslim tidak boleh menjual sesuatu yang tidak ada padanya atau sesuatu yang belum dimilikinya, karena hal tersebut menyakiti pembeli yang tidak mendapatkan barang yang dibelinya.

7) Jual beli buah-buahan. Jika seorang muslim menjual pohon kurma yang telah berbuah, atau pohon yang telah berbuah, maka buahnya menjadi milik penjual. Kecuali, jika pembeli mensyaratkan bahwa buah tersebut menjadi miliknya. Namun, jika ia tidak mensyaratkan maka buah menjadi milik penjual.

d. Terlarang sebab shara'

Ulama sepakat membolehkan jual beli yang memenuhi persyaratan dan rukunnya. Namun demikian, ada beberapa masalah yang diperselisihkan diantara para ulama, yaitu:

1) Jual beli riba. Riba nasiah dan riba fadl adalah fasid menurut ulama Hanafiyah, tetapi batal menurut jumhur ulama. 
2) Jual beli dengan uang dari barang yang diharamkan. Menurut jumhur ulama adalah batal sebab ada nash yng jelas dari hadits Bukhari Muslim bahwa Rasulullah SAW mengharamkan jual beli khamr, bangkai, anjing dan patung.

3) Jual beli hasil pencegatan barang. Jika seorang muslim mendengar komoditi barang telah masuk ke daerahnya, ia tidak boleh keluar dari daerahnya untuk menemui penjual diluar daerah tersebut, lalu kemudian membelinya disana dan membawa masuk barang tersebut kemudian menjualnya dengan harga semaunya, karena cara pembelian seperti ini menipu penjual (pemilik komoditi) dan merugikan penduduk daerahnya para pedagang.

4) Jual beli pada saat adzan jum'at. Seorang muslim tidak boleh menjual sesuatu atau membeli sesuatu jika adzan kedua shalat jum'at telah di kumandangkan dan sang khatib telah nak mimbar.

5) Jual beli anggur yang dijadikan khmar. Menurut ulama Hanafiyah dan Shafi'iyah zahirnya sahih, tetapi makruh, sedangkan ulama Malikiyah dan Hanabilah adalah batal.

6) Jual beli barang yang sedang di beli oleh orang lain. Seseorang telah sepakat akan membeli suatu barang, namun masih dalam khiyar, kemudian datang orang lain yang menyuruh untuk membatalkannya sebab ia akan membelinya dengan harga lebih tinggi

7) Jual beli bersyarat. Jual beli yang ijab qabulnya dikaitkan dengan syarat-syarat tertentu yang tidak ada kaitannya dengan jual beli atau ada unsur-unsur yang merugikan dilarang olah agama. Contohnya seperti: "Baik, mobilmu akan kubeli sekian dengan syarat anak gadismu harus menjadi istriku". Atau sebalimya si penjual berkata: "Ya, saya jual mobil ini kepadamu sekian asal anak gadismu menjadi istriku" (Ghazaly, 2010)

\section{M etode Penelitian}

Jenis penelitian yang digunakan adalah kualitatif dengan pendekatan studi pustaka dan wawancara di lapangan. Penelitian dilaksanakan di kampus IAIN Ponorogo pada enam fakultas yaitu Fakultas Syariah, Fakultas Ekonomi Bisnis Islam, Fakultas Tarbiyah dan IImu Keguruan, dan Fakultas Ushuluddin, Adab dan Dakwah.

\section{Hasil dan Diskusi}

Transaksi jual beli di dunia maya atau ecommerce adalah kegiatan komunikasi komersial bisnis dan manajemennya yang dilaksanakan menggunakan metode-metode elektronik seperti hal nya electronic data interchange dan automated data-collection systemi. E-commerce juga dapat meliputi transfer informasi secara elektronis antarbisnis, dalam hal ini menggunakan Electronic Data Interchange (EDI). Ecommerce adalah kegiatan-kegiatan bisnis yang menyangkut konsumen (consumers), manufaktur (manufactures), service providers dan pedagang penata (intermediaries) dengan menggunakan jaringanjaringan komputer (computer network) yaitu internet. (Mustofa, 2016).

Sarana transaksi juga menggunakan berbagai sarana yang ada di dalam dunia maya. Transaksi di dunia maya umumnya menggunakan media sosial, seperti twitter, facebook, blackberry messenger dan media sosial lainnya. Dalam transaksi di dunia maya, antara para pihak yang bertransaksi tidak bertemu langsung, akan tetapi dapat berkomunikasi langsung, baik secara audio maupun audio visual. Selain itu, komunikasi antara keduanya dapat melalui tulisan, seperti inbox via facebook, via Short M essage Service/SM S, via email dan media tulisan lainnya yang disediakan di dunia maya. Akad 
dalam transaksi elektronik di dunia maya berbeda dengan akad secara langsung. Transaksi elektronik biasanya menggunakan akad secara tertulis, (E-mail, Short Message Service/SMS, Blackberry M essengger/B BM dan sejenisnya) atau menggunakan lisan via telepon atau video seperti tel econference.

A nalisis P endapat $M$ ahasiswa Terhadap Jual Beli M elalui M edia 0 nline Jual beli merupakan proses tukar menukar barang dengan barang atau barang dengan uang yang dilakukan dengan jalan melepaskan hak milik dari yang satu kepada yang lain atas dasar saling merelakan sesuai dengan perjanjian atau ketentuan yang telah dibenarkan shara' dan disepakati (Nisrina, 2015). Jual beli adalah suatu perjanjian tukar menukar benda (barang) yang mempunyai nilai, atas dasar kerelaan (kesepakatan) antara dua belah pihak sesuai dengan perjanjian atau ketentuan yang dibenarkan oleh syara'. Suatu jual beli haruslah memenuhi rukun dan syarat jual beli, diantaranya ialah orang yang berakad (penjual dan pembeli), shighat ijab qabul, ada barang yang dibeli, dan ada nilai tukar pengganti barang. Akad merupakan hal yang paling diutamakan dalam jual beli. Jika dalam jual beli tidak ada akad maka jual beli itu tidak mungkin akan terjadi. Karena akad merupakan berkumpulnya serah terima di antara dua belah pihak atau perkataan seseorang yang berpengaruh pada kedua belah pihak (A bidah, 2006).

Hasil data penelitian sesuai dengan pembahasan di bab sebelumnya yang diperoleh dari mahasiswa IAIN Ponorogo, bahwa hampir semua mahasiswa yang melakukan jual beli online berpendapat dalam melakukan kegiatan transaksi jual beli melalui media online itu mudah dan praktis. Tidak harus bertemu langsung dengan customer atau owner. Dan pengambilan barang bisa dikirim melalui jasa kurir yang sudah tersedia. Selain itu juga, menurut mereka dengan melalui media online tidak sulit untuk memasarkan produk yang akan dijual ataupun yang akan dibeli karena hanya dengan memposting produk jualan atau melihat toko-toko online ke sosial media atau internet semua kalangan bisa melihat produk atau barang apa yang diposting dan tidak perlu menyewa atau membeli kios untuk membuka lapak jualan. Hanya saja kelemahan dalam jual beli media online ialah di saat masa pengiriman barang, yang terkadang terjadi overload barang jadi barang sampai ketujuan tidak sesuai jadwal yang sudah ditentukan.

Dalam kegiatan jual beli harus ada perjanjian tukar menukar barang yang mempunyai nilai, dasar kerelaan (kesepakatan) antara dua belah pihak dan harus sesuai dengan perjanjian atau ketentuan shara'. Kegiatan jual beli harus memenuhi rukun dan syarat jual beli. Kalau salah satu rukun jual beli dan syarat jual beli tidak terpenuhi maka kegiatan jual beli tersebut tidak sah. Dalam praktek kegiatan jual beli yang dilakukan oleh mahasiswa IAIN Ponorogo yaitu sesuai dengan rukun dan syarat hukum sha>ra>'. Orang yang berakad adalah mahasiswa yang bisa menjadi pembeli atau pun penjual. Dan akad yang dilakukan ialah melalui alat komunikasi atau gawai. Dan ijab qabul atau biasanya dalam proses ini mereka melakukan proses transaksi tanya jawab mengenai barang yang akan di beli oleh customer atau bisa juga mengenai penjelasan lebih detail tentang barang yang dijual. Dan proses tersebut dilakukan melalui alat komunikasi juga.

Jadi, dapat disimpulkan bahwa jual beli yang dilakukan oleh semua mahasiswa sudah sesuai dengan teori jual beli, dalam teori jual beli adalah saling menukar harta dengan harta dalam bentuk pemindahan milik dan pemilikan (Afandi, 2009). Jual beli memiliki beberapa hal yang harus ada terlebih dahulu agar akadnya dianggap sah dan mengikat. Beberapa hal tersebut kemudian disebut rukun dan syarat dalam proses transaksi jual beli. Dalam proses transaksi yang mereka lakukan apabila mereka sudah deal atau sepakat, maka secara tidak langsung mereka sudah saling rela dalam melepas barang yang mereka jual dan pembeli pun rela untuk membayar barang yang akan di beli. 
A nalisis Hukum Ekonomi Syariah Terhadap Jual Beli M elalui M edia O nline di Kalangan M ahasiswa

Perdagangan merupakan kegiatan sosial dan ekonomi dalam aktifitas hidup dan kehidupan manusia dalam rangka memenuhi kebutuhan hidupnya sehari-hari sebagai manusia yang berperilaku ekonomi. Walaupun demikian sebagai manusia yang "Islamnya Kaffah" dalam perdagangan, bisnis atau perniagaan tidak boleh lepas dari nilai-nilai ke Islaman yang telah tertuang dalam hukum perdata Islam dan selalu menjunjung tinggi etika bisnis. Dalam literatur bisnis juga disebut perdagangan dal am arti sempit. Dalam arti luas bisnis merupakan usaha yang berkaitan dengan dunia ekonomi dan politik (Nawawi, 2012).

Jual beli online atau bisa disebut dengan E-commerce dalam bahasa Indonesia dikenal dengan perniagaan via elektronik. Di dalam Kompilasi Hukum Ekonomi Syariah Pasal 20 ayat (3) secara definitif, ecommerce adalah suatu aktifitas perniagaan seperti layaknya perniagaan pada umumnya, hanya saja para pihak yang bertransaksi tidak bertemu secara fisik akan tetapi secara elektronik mereka berkomunikasi melalui media internet. (Mardani, 2013)

Jual beli merupakan suatu peristiwa di mana seseorang menyerahkan barangnya, dengan mendapatkan sejumlah uang atau harta (yang selanjutnya disebut penjual), kepada orang lain yang mana ia menyerahkan sejumlah ganti rugi, barang yang akan ia terima sebagai harga kepada penjual (yang selanjutnya disebut sebagai pembeli), setelah ada persetujuan di antaranya mengenai barang dan harganya dengan dasar sama-sama rela serta ridha atas keduanya. (Huda, 2011).

Pada zaman modern sekarang ini, dimana zaman sudah dipenuhi dengan peralatan teknologi yang serba canggih orang memilih melakukan segala sesuatunya dengan mudah dan instan. Transaksi jual beli yang sudah melekat di kalangan masyarakat dari dulu hingga kini merupakan sesuatu yang prioritas untuk bisa memenuhi kebutuhan sehari-hari. Pada masa kini itu bisa dilakukan dengan mudah melalui internet. Meskipun hanya sebagian saja yang suka bertransaksi dengan cara ini bahkan mungkin ada yang belum mengetahui caranya, tapi kebanyakan orang khususnya orang-orang di perusahaan lebih banyak memilih untuk bertransaksi online karena dianggap lebih cepat, mudah, praktis, dan juga terjamin (Pratama, 2018).

Mengenai objek e-commerce harus memenuhi syarat objek akad, yaitu:

1. Telah ada pada waktu diakadkan

Mahasiswa yang melakukan jual beli online sudah pasti ada barangnya meskipun mereka mahasiswa yang sebagai penjual tidak menyetok barang dagangan di rumah. Dan penjual online pun juga memposting barang dagangannya ke media sosial sudah pasti barang yang dipasarkan tersebut ada atau siap untuk dikirim ke pembeli online.

2. Dibenarkan oleh syariah (halal dan bermanfaat)

Mengenai barang yang dijual oleh para mahasiswa ialah barang yang sebgaian besar sangat bermanfaat bagi para pembeli. Misalnya saja pembeli online membeli baju, hijab, sepatu, tas, aksesoris gadget, dan lain-lainnya lagi. Dan para mahasiswa pun menjual barang ialah barang yang bermanfaat bagi pembeli online atau mahasiswa yang berstatus pembeli. 
3. Harus jelas dan diketahui

Para mahasiswa yang berstatus penjual online memposting barang di sosial media mereka sangat jelas dan dapat diketahui gambar, model dan bahannya.

4. Dapat di serah terimakan

Barang yang sudah dipilih atau dipesan oleh pembeli online dapat diserah terimakan setelah pembeli melakukan pemayaran melalui online atau transfer melalui bank. Setelah melakukan transfer atau pembayaran, maka penjual pun mengirimkan barang pesanan milik pembeli melalui pengiriman jasa kurir.

Dari penjelasan dari bab sebelumnya tentang jual beli melalui media online, dapat dikatakan bahwa jual beli tersebut adalah dibolehkan. Alasannya, karena jual beli melalui media ialah termasuk aspek muamalah yang pada dasarnya boleh, kecuali ada dalil yang mengharamkannya menurut kaidah figh. Kaidah ini menegaskan bahwa segala bentuk muamalah yang direkayasa manusia pada dasarnya adalah dibolehkan atau diizinkan. Dan juga ada kaidah fiqih lain yang khusus pembahasannya di bidang muamal ah jual beli di dalam kitab Q awaid al-Buyu wa Faraid alFuru' karya Walid bin Rashid Sa'idan yang berbunyi:

"Prinsip dasar dalam muamalah adalah halal dan boleh"

الاصل فن المعاملة الحل والاباحة

Maksud kaidah di atas ialah semua akad dipandang halal, kecuali ada dalil yang mengharamkannya. Dalam persoalan muamalah, "pintu" terbuka luas. Setiap muamalah baik yang datang kemudian atau yang terdahulu prinsip dasarnya adalah boleh. Tidak boleh seseorang mengintervensi hukum kebolehan tersebut, kecuali ada dalil yang shahih dan jelas yang melarangnya (Hidayat, 2015). Dengan demikian jual beli via telepon adalah sama kekuatan hukumnya dengan ungkapan tulisan. Sementara jual beli via internet atau online sama dengan bentuk jual beli Iainnya yang dilakukan dengan media surat-menyurat. Ungkapan, baik tulisan maupun isyarat (seperti orang gagu), kata Ibrahim al-Bajuri, merupakan bagian dari 'an-tarad\{in yaitu prinsip suka sama suka (Mardani, 2011).

\section{Kesimpulan}

Kesimpulan

Kesimpulan yang diperoleh dari penelitian ini adalah: pertama, pendapat mahasiswa IAIN Ponorogo mengenai jual beli melalui media online itu sangat memudahkan dalam bertransaksi online termasuk dalam proses jual beli melalui media online. Para mahasiswa selaku penjual online maupun pembeli online sangat merasakan kemanfaatan jual beli melalui media online. Dengan jual beli melalui media online penjual ataupun pembeli online tidak harus saling bertemu satu sama lain, media yang sangat mudah digunakan, praktis, menghemat waktu, menjangkau keseluruh pengguna internet di media sosial, harga lebih terjangkau, banyak pilihan barangnya, tidak perlu menyewa ruko atau membangun ruko untuk memulai usaha, tidak perlu memasok barang bagi penjual dan bisa promosi barang setiap waktu dan setiap saat kapan pun dan juga tidak memerlukan modal banyak untuk memulai usaha. Kedua, Hukum ekonomi syariah terhadap jual beli melalui media online di kalangan mahasiswa IAIN Ponorogo boleh (mubah), transaksi yang di laksanakan sudah sesuai dengan rukun dan syarat jual beli.

Implikasi 
Pada dasarnya jual beli ialah bertemunya penjual dan pembeli secara langsung. Namun, sesuai dengan perkembangan zaman jual beli bisa melalui media online. Jual beli online termasuk aspek muamalah yang pada dasarnya mubah (boleh), kecuali ada dalil yang mengharamkannya, selama proses jual beli tidak melanggar rukun jual beli dan tidak ada unsur penipuan dan kebohongan dalam proses transaksi jual beli.

Keterbasan

Penelitian dilakukan hanya pada salah satu perguruan tinggi sehingga tidak menggambarkan pendapat mahasiswa di luar wilayah penelitian. Penelitian mendatang perlu memperluas wilayah studi dan mengambil subjek penelitian yang lebih luas untuk mendalami dasar perilaku mahasiswa tertarik menggunakan bisnis online.

\section{Daftar Pustaka}

Abidah, A. (2006). Figh M uamalah. Ponorogo: STAIN Po Press.

Afandi, Y. (2009). Fiqih M uamalah D an Implementasinya Dalam Lembaga Keuangan Syari'ah. Yogyakarta: Logung Pustaka.

Adam, H. E-Commerce: M odel Interaksi Jual Beli (Studi Pada Pelaku Interaksi Jual Beli M elalui Internet) dalam https:/ / www.researchgate.net/ publication/ 316452392/ E-Commerce-Interaksi-Jual-Beli(Studi-Pada-Pelaku-Interaksi-Jual-Beli-Melalui-Internet). Diakses pada tanggal 30 April 2019, Jam 10:47.

Badriyah, H. (2012). Rahasia Sukses Besar Bisnis O nline Tanpa M odal. Jakarta: Kunci Komunikasi.

Fitria, T. N. (2017). Bisnis jual beli online (online shop) dalam Hukum Islam dan Hukum Negara. Jurnal IImiah Ekonomi Islam, 3(01), 52-62.

Firmansyah, J. A., \& Widodo, A. (2019). Transaksi Jual Beli Online Di Blibli. Com Ditinjau Dari A kad AsSalam Dan Undang-Undang No. 11 Tahun 2008 Tentang Informasi Dan Transaksi Elektronik (Doctoral dissertation, IAIN SURAKARTA).

Ghazaly, A. R. (2010). Fiqih M uamal ah. Jakarta: Prenada Media Group

Hidayat, E. (2015). Fiqih Jual Beli. Bandung: PT Remaja Rosdakarya.

Hendiana, R., \& Aly, A. D. (2016). Transaksi Jual Beli Online Perspektif Ekonomi Islam. A I-M ustashfa: Jurnal Penelitian Hukum Ekonomi Syariah, 3(2).

Huda, Q. (2012).. Fiqh M uamalah. Yogyakarta: Teras.

Anonim. (2016). Kitab Undang-Undang (KUHPer, KUHP, KUHAP) Beserta Penjelasannya. Grahamedia Press.

Igen, R. (2011). Strategi Sukses Berjualan O nline. Jakarta: Mediakita

Lestari, W., \& Wahab, A. (2018). Tinjauan Hukum Islam Terhadap Objek Akad Jual Beli Online Dengan Sistem Dropshipping Di Toko Online Princess Shop. M A Q A SID , 5(1).

Lestari, W., \& Wahab, A. (2018). Tinjauan Hukum Islam Terhadap Objek Akad Jual Beli Online Dengan Sistem Dropshipping Di Toko Online Princess Shop. M A Q A SID , 5(1).

Mardani, (2011). Hukum Ekonomi Syariah di Indonesia. Bandung: PT Reflika Aditama.

Nawawi, I. (2012). Fikih M uamalah dan Kontemporer Hukum Perjanjian, Ekonomi, Bisnis dan Sosial. Ghalia Indonesia, 2012.

-------. (2012). Fikih M uamal ah Klasik dan Kontemporer. Bogor: Ghalia Indonesia

------. (2010). Fiqih M uamal ah H ukum E konomi, Bisnis dan Sosial. Putra Media Nusantara

Nisrina, D. N. (2015). Tinjauan Hukum Islam Terhadap Jual Beli Online Dan Relevansinya Terhadap Undang-U ndang Perlindungan Konsumen. Skripsi, UIN Alauddin Makassar.

Purwanto, L. S. (2018). Tinjauan hukum ekonomi syariah terhadap jual beli sistem dropshipping di toko online razordistro. com (Doctoral dissertation, UIN Sunan Gunung Djati Bandung).

Pratama, D A. (2018). Transaksi Jual Beli Secara Online Dalam Pandangan Hukum Islam. Skripsi, UIN Syarif Hidayatullah Jakarta.

Pusat Pengkajian Hukum Islam dan mAsyarakat Madani. (2009). Kompilasi H ukum Ekonomi Syariah. Jakarta: Kencana.

Rozalinda. (2016). Fiqih E konomi Syariah: Prinsip dan Implementasi Pada Sektor Keuangan Syariah. Jakarta: PT Raja Grafindo Persada, 
Syafe'i, Rachmat. Fiqih Muamalah untuk UII, STAIN, PTAIS dan Umum. Jakarta: Pustaka Setia, 2006Nawawi, A., \& Imron Rosyadi, M. A. (2019). Tinjauan Hukum Islam terhadap Jual B eli O nline di Bukalapak. Com (Doctoral dissertation, Universitas Muhammadiyah Surakarta).

\section{A bout Authors}

Zuhrotul M ahfudhoh dan Lukman Santoso adalah mahasiswa dan dosen dari Institut Agama Islam Negeri Ponorogo (IAIN) Ponorogo. Corresponding author: Lukman Santoso (email: lukmansantoso4@gmail.com)

Accepted author version posted online: 30 April 2020

$$
\text { (c) (1) }
$$

(C) 2020 The Author(s). This open access article is distributed under a CreativeCommons Attribution (CC-BY) 4.0 license 